\title{
Iranian high school students' beliefs about language learners: A qualitative study
}

\author{
Nader Assadi Aidinlou ${ }^{1}$, Fahime Farjami ${ }^{2}$, Ali Rezaee Javidan ${ }^{1}$ \\ ${ }^{1}$ Department of English Language Teaching, Ahar Branch, Islamic Azad University, Ahar, Iran \\ ${ }^{2}$ Young Researchers and Elite Club, Ahar Branch, Islamic Azad University, Ahar, Iran
}

\section{Email address:}

naderasadi@yahoo.com (N. A. Aidinlou), fahimefarjami@yahoo.com (F. Farjami), a.r.javidan@gmail.com (A. R. Javidan)

\section{To cite this article:}

Nader Assadi Aidinlou, Fahime Farjami, Ali Rezaee Javidan. Iranian High School Students' Beliefs about Language Learners: A Qualitative Study. International Journal of Language and Linguistics. Special Issue: Foreign Language Teaching and Learning (Models and Beliefs). Vol. 2, No. 3-1, 2014, pp. 21-31. doi: 10.11648/j.ijll.s.2014020301.13

\begin{abstract}
This study aims at examining the metaphors created by two groups of language learners in Iranian high schools (43 males and 43 females) in Famenin. Learners were required to write the metaphors which truly conceptualized their perceptions of the English educational system in Iran. Their metaphors were categorized based on the taxonomy developed by the scholars in the field (Martinez, 2001). The results highlighted remarkable points which the most important one is that; in Iran, still, most of learners work based on the principles of the behaviorists, these findings are compatible with those of Pishghadam and Mirzaee (2008) and Pishghadam et al. (2011) which asserted that Iran's educational system is still under the influence of modernist, behaviorist and positivist views of learning.
\end{abstract}

Keywords: Metaphor, High School, Linguistic Metaphor, Beliefs and Conceptions, Conceptual Metaphor, Metaphor Analysis

\section{Introduction}

During the teaching- learning process, nowadays, learner has received special attention. That is, if we want to have clear guidelines to how to organize the language classroom, we need to understand what the learner is. In this regard Larsen-Freeman (1986) claim, "a teacher informed about some of the possibilities will make better decisions" ( $\mathrm{p} 1$ ). so, it is important to understand what being the language learner means, especially in various socio-cultural and educational settings. To understand what being the language learner means, one should study different characteristics and effects on learning process a learner has.

Learners can affect learning in many different ways. Their age, sex, level, culture, background knowledge, individual differences, attitude, the way of thinking, beliefs, thoughts, and values about language learning process and its components are some of these important factors. Among which, their beliefs, thoughts, and values about language learning process and its components, their attitudes toward and/or the way they think of learning and teaching process, are some of the most important ones. Understanding these beliefs, thoughts, and values about language learning process and its components, will help to have a very better view of the learner and as a result a very better learning.

One way to obtain the understanding of beliefs is through an analysis of metaphors language learners produce. Metaphors are one of the most effective means to find out individuals' mental perceptions. According to Lakoff and Johnson (1980)'s Metaphors We Live By; [M]etaphor is pervasive in everyday life, not just in language but in thought and action. Our ordinary conceptual system, in terms of which we both think and act, is fundamentally metaphorical in nature. (p.3)

According to Skaftun (2011), the idea of bridging the individual and the social - in itself a metaphor - is old. Based on Siqueria et al. (2009), in recent decades, the phenomenon of the metaphor has increasingly gained attention, especially in the works of linguists and philosophers, and has been a focus of interest for researchers in lexical studies and its related disciplines ( $p$ 158). So, research in the field of language teaching and learning has extensively used metaphors as to develop a better understanding of learners' beliefs, thoughts, and values about language learning process and its components (Kesen 2010, p 108) 
Pishghadam \& Pourali (2011), claim that: It seems that analyzing metaphors has become a powerful tool of expression, figure of speech and a basic vehicle for communication and reflection of social images and thoughts (p 63). And according to Botha (2009), there is a widespread recognition of the fact that metaphors play a significant aesthetical, ornamental and pedagogical role not only in literature but also in education. (p 431)

Gunbayi (2011) illustrates that metaphors can be used by researchers to; reduce data, develop themes, explicit metaphor analysis, secondly, assist in understanding a wellknown process in a new light, to suggest suitable or acceptable interventions and insight into potential interventions which are situation specific and to evoke emotions. (p 542)

Glogowski (2012) sees metaphors which are not imposed on us by outside forces but grow from within, based on our own understanding of who (and where and how) we are, act as lenses that allow for imaginative expression of our professional and personal selves while also ensuring a connection to and a critical examination of our teaching practice (p 2).And as Samani \& Hashemian (2012) note, metaphor is an important means of expression in human languages, used in both spoken and written discourse.

Thereforeby recognizing and analyzing the metaphors that the learners use to depict their teachers and teaching process, language teachers can enter the minds of their learners in order to 'adjust intimacy and shorten the distance between them. Another benefit of metaphor is that lets students discuss their success and failure, to find and define their hindering and also positive beliefs about language, as well as using metaphor to get close or distance from the learning process. Therefore, this study aimed at analyzing the metaphors Iranian learners at high school used to describe the current and ideal situations of teaching in order to find the problematic areas in our education. Because I believe that analyzing high school students' metaphors and delving into their implications may enhance our knowledge about learning in general and inform language teaching and learning at school practice in particular.

\section{Review of Related Literature}

Many studies have investigated on metaphor and its different types as a very important phenomenon in our 'everyday life', which gathering information and talking about all of them will certainly be a very great and big work. Here, we do not have the needed time and space to refer to all those great works; from Aristotle, Richards (1936), Lakoff \& Johnson (1980\& 1999), Lakoff (1987, 1992), to Gibbs (2008), Kövecses (2010) and so many others. Most of these books try to give a clear understanding of the word and sometimes try to differentiate between different types of it, such as; 'linguistic' and 'conceptual metaphor'. Besides, a lot of researchers used metaphor analysis as a tool for achieving the underlying thoughts, beliefs and perceptions in describing current situations and improving those situations to better ones.[Kesen, (2010); Nikitina and Furuoka, (2008; a \& b); Ellis, (2008); Pishghadam, (2008); Pishghadam, Fatemi, Askarzadeh Torghabeh and Navari, (2011); Martinez, Sauleda, \& Huber, (2001); and etc.]

Here, I am to take a brief look at some of these works, whose authors are distinguished scholars from different academic fields who have done important work on metaphor and related poetic figures. This review will help us to have a better understanding of what have been done and what I am going to do.

In their study, Pishghadam \& Pourali (2011) explored the nature of unconscious beliefs of PhD students. Using a qualitative research methodology they tried to uncover and analyze the hidden beliefs and discuss the ideas behind them. The results revealed that $\mathrm{PhD}$ university students concur with forming the foundation of learning and teaching based on situative learning concepts. The $\mathrm{PhD}$ students prefer to follow the guidelines of situative paradigm to make use of the appropriate contexts in which they can prepare for skills needed in their real life practice of teaching. Maybe the noteworthy point of this study is that, surprisingly, no metaphors were attributed to the behaviorist views that can explain the desired modification in students' views points. Therefore they conclude that analyzing the results of the created metaphors for professors and students in the ideal situation shows that situative perspective wins an absolute majority and transferring such ideas into their teaching career, $\mathrm{PhD}$ students can be the forerunners of a new era of teaching in the Iranian educational system. Looking at the implication aspect of their findings, Pishghadam \& Pourali (2011) emphasize on the importance of disclosing the students' hidden beliefs and its effect on selecting the appropriate styles for learning and teaching. (p 68)

In another study, Pishghadam \& Pourali (2011) explored metaphors produced by M.A. students. They tried to uncover, analyze and discuss the metaphors and hidden beliefs and ideas behind them through a qualitative research methodology. The results showed that behaviorism [classical roles of teacher] dominates the current environment in the process of teaching. On the contrary to the metaphors about current situation teachers and learners, Pishghadam \& Pourali (2011) found that learners have a meaningful tendency toward situative approach to learning and the conceptual metaphor of TEACHER AS FACILITATOR and LEARNER AS INTERACTOR in the ideal situation.

Due to probable existence of problems between L2 learning and teaching at schools and language institutes in our education, Pishghadam, et al. (2011) in a study, in addition to analysis of metaphors, made a comparison between the school and language institute learners' use of metaphors. To do this, they used a metaphoric model of three main dimensions of the learning space: behavioristic /empiricist, cognitive/constructive and situative /sociohistoric perspective whose guidelines were taken from a 
study by Martinez, Sauleda, and Huber (2001). They triedto trace the roots of disapprovals in Iranian formal and informal contexts of English language education. Having discussed the issues, the participants filled out the forms. The results of metaphor analysis mostly were in consistence with that of Pishghadam \& Pourali (2011) and showed that in the current situation the most of metaphors for the school learners are in the behaviorist category. But On the contrary to current situation, school learners' perspective about the ideal situation mostly implies that they no longer like to be under the umbrella of behaviorism, instead they would rather have a facilitator teacher in the class who provides a friendly atmosphere for them to learn meaningfully.

\section{Research Questions}

This study aims at answering the following questions:

1. What are the metaphors produced by Iranian high school students of English about English learners in current/ ideal situations?

2. Is there asignificant relationship between gender and the type of metaphors produced?

\section{The Present Study}

\subsection{Subjects}

To carry out the study, a group of 43 male language learners at Imam Ali High school and a group of and 43 female learners at Farzanegan High school, both in Famenin (a city in Hamadan North East), Iran were selected. All the students were studying in the fourth grade of high school and had passed the nationwide English exam at the end of grade three. All of them were eager in taking part in the study. The average age of the students was 18, having studied English at schools for almost 7 years, with no experience of studying English at private institutes.

\subsection{Data Collection: Instrumentation}

In order to collect data, first, the researcher informed the participants about the aim and procedures of the research and survey, one by one, and of course gave some guidelines, and examples of metaphors about teachers in a table developed by Pishghadam et al. (2011) (see Appendix B) to clarify what the researcher meant by the given questions. Although the written instructions were clearly worded in Persian (since it was difficult for most of the learners to express their ideas with the English equivalents and the purpose of the study was mainly to collect their ideas, the questionnaire was set in Persian), they were also explained orally when the questionnaire was given to each respondent so that there was a clear understanding as to what s/he was expected to do. Practically in all cases the questionnaire was handed to individual respondents in person, by the researcher. Then, as for the instrument, the participants were asked to complete a questionnaire. In order to address the research questions, the participants were asked to fill out the questionnaire which was based on the one designed by Pishghadam, et al. (2009), which was adapted to high school situation in Iran. The administered questionnaire consisted of two questions:

"1. What is your idea of a high school learner?"

"2. What is your idea of an ideal high school learner?"

The reason for administering such prompting was realizing the participants' attitudes towards the learners in current and ideal situations. They were asked to complete these questions with as many metaphors as they prefer to mention to describe the learners. Finally, the forms were also returned individually. This introduced a bias into this study as the metaphors were likely to come from those participants who were eager about language learning and accordingly the concepts of those with less enthusiasm and less positive attitudes are not included.

\subsection{Data Analysis}

Filling the questionnaire, the subjects created metaphors about learners which were categorized and analyzed based on the guidelines suggested by Martinez et al. (2001): behaviorist/empiricist, cognitive/constructive, situative or socio- historical perspective. To have a brief look at these categories, I try to clarify them; In the behaviorist/empiricist view, as the title speaks teaching and learning process is considered as a kind of behavior or habit formation through experiencing. As Yillmaz (2010) notes, behaviourists believe that the teacher's function is to transmit or provide information, which makes learner a recipient of knowledge. (p 11) There is no role for the brain and cognitive aspect of learning in this view. Unfortunately, as the results of different studies show, despite of the obvious shortcomings, weaknesses, failures and disadvantages of this approach, in Iran, there are many teachers and professors who use it in different contexts, even in universities. (See Pishghadam et al., (2011); Pishghadam, (2008); Pishghadam, et al. (2009); Pishghadam and Mirzaee (2008); Pishghadam \& Pourali (2011))

In the second view the cognitivist/constructivist perspective; Cognitive psychologists and transformationalgenerative linguists argued that learning is not just mimicry, rather learners form rules, which allow them to understand and create novel utterances (Larsen-Freeman, 1986). Where Yillmaz (2010) notes: "Cognitive Learning is an individual construction of knowledge, and this perspective focuses more on the students' notions of the elaboration and organization of knowledge, active role, understanding of concepts, intrinsic motivation and transfer". In this way, the cognitivist/constructivist perspective consists of those metaphors which view knowledge as consisting of interrelated schemata that are actively and individually constructed by transferring old schemata into new ones or by inductively developing new schemata from a series of different experiences (Pishghadam et al., 2011).

Since the fundamental goal of learning any languages is the communication, in situative view of learning, the 
dominant belief is that learners should become able to interact with the physical world. In this regard Yillmaz (2010) claims that socio-cultural learning is a participation in the activities in the social community (class) in the search of knowledge. Metaphors arising from a situative or socio-historical perspective reflect the view that learning is situated in the context in which it is used. In this category teacher can be seen as the North Star guiding the explorers (learners) to find their way during the journey of learning. Teacher and learners can perform a joint job, working collaboratively to get a result (Pishghadam et al., 2011). That is, in this view, the learners should be provided by real life like situations, and should be given the opportunities to express themselves, their ideas and opinions, errors are tolerated and seen as a natural outcome of the development of communication skills. According to Larsen-Freeman (1986), the teacher as an advisor encourages cooperative relationships among students. The other obvious characteristic of this view is that learning activities are joyful and adventurous-type ones.

\section{Results}

As Table 1 shows, results of the analyses of the metaphors produced by both male and female learners revealed a meaningful contrast between the learners in current and ideal situations. That is, while more than half of the participants $(\mathrm{p}=54.70 \%)$ think of current learners as a behaviorist, nearly all of them $(\mathrm{p}=81.03 \%)$ wish to have a more cognitivist and/or situativist one.
Table 1. Summary of the main categories of metaphors of both male and female learners.

\begin{tabular}{cccccccc}
\hline & \multicolumn{2}{c}{ Behavioristic } & \multicolumn{2}{c}{ Cognitivist } & \multicolumn{2}{c}{ Situative } & \multirow{2}{*}{ Total } \\
\cline { 2 - 6 } & $\mathbf{F}$ & $\mathbf{P}$ & $\mathbf{F}$ & $\mathbf{P}$ & $\mathbf{F}$ & $\mathbf{P}$ & \\
\hline $\begin{array}{c}\text { Current } \\
\text { learner }\end{array}$ & 64 & 54.70 & 27 & 23.08 & 26 & 22.22 & 117 \\
$\begin{array}{c}\text { Ideal } \\
\text { learner }\end{array}$ & 22 & 18.97 & 45 & 38.79 & 49 & 42.24 & 116 \\
\hline
\end{tabular}

\subsection{Male Learners}

\subsubsection{Current Learners in Male Learners Point of View}

As Table 2 exhibits, in current learners case, also the majority of male learners' metaphors belong to the behaviorist domain $(\mathrm{p}=58 \%)$, which is compatible with that of current teachers ( $\mathrm{p}=53.19 \%)$, and these learners' belief about themselves completes their previously mentioned ideas about the teacher, where the teacher considers them as sheep $(\mathrm{p}=14 \%)$, passive participants in the class, memory cards, empty glasses $(\mathrm{p}=6 \%)$ waiting to be filled by the teacher's knowledge. Perhaps Figure 4.3 is more helpful than numbers in comparing the three domains - that is behavioristic, cognitivist and situativist - where the first category is larger than the sum of the two other categories. Thus, in current situation, the LEARNERs AS RECIPIENT are dependent creatures, who cannot make any decisions in their learning process, instead the authority, the dictator, the monster, the teacher, makes all needed decisions alone. The learners are seen very weak $(\mathrm{p}=8 \%)$ and uninterested $(\mathrm{p}=4 \%)$. Thus they cannot do anything alone, and everything should be planned, done and ordered to them.

Table 2. The frequency and percentage of male learners' metaphors for learners in the current situation.

\begin{tabular}{|c|c|c|c|c|c|c|c|c|c|}
\hline BEH. & $\mathbf{F}$ & $\mathbf{P}$ & COG. & $\mathbf{F}$ & $\mathbf{P}$ & SIT. & $\mathbf{F}$ & $\mathbf{P}$ & Total \\
\hline sheep & 7 & 14 & friend & 1 & 2 & fast train & 1 & 2 & \\
\hline empty glass & 2 & 4 & good company & 2 & 4 & star & 2 & 4 & \\
\hline weak & 4 & 8 & doctor assistant & 1 & 2 & flower & 1 & 2 & \\
\hline wall & 2 & 4 & player & 3 & 6 & inventor & 1 & 2 & \\
\hline robot & 1 & 2 & baby & 3 & 6 & passenger & 1 & 2 & \\
\hline eye & 2 & 4 & & & & thirsty & 3 & 6 & \\
\hline mirror & 2 & 4 & & & & tourist & 1 & 2 & \\
\hline watch & 1 & 2 & & & & customer & 1 & 2 & \\
\hline memory card & 1 & 2 & & & & & & & \\
\hline statue & 1 & 2 & & & & & & & \\
\hline uninterested & 2 & 4 & & & & & & & \\
\hline dictionary & 1 & 2 & & & & & & & \\
\hline scale & 2 & 4 & & & & & & & \\
\hline Vacuum cleaner & 1 & 2 & & & & & & & \\
\hline TOTAL & 29 & & & 10 & & & 11 & & 50 \\
\hline TOTAL & & 58 & & & 20 & & & 22 & \\
\hline
\end{tabular}

\subsubsection{Ideal Learners in Male Learners Point of View}

Table 3. The frequency and percentage of male learners' metaphors for learners in the ideal situation.

\begin{tabular}{|c|c|c|c|c|c|c|c|c|c|}
\hline BEH. & $\mathbf{F}$ & $\mathbf{P}$ & COG. & $\mathbf{F}$ & $\mathbf{P}$ & SIT. & $\mathbf{F}$ & $\mathbf{P}$ & Total \\
\hline memory card & 1 & 2 & doctor assistant & 6 & 12 & tourist & 1 & 2 & \\
\hline empty glass & 1 & 2 & good company & 1 & 2 & lawyer client & 1 & 2 & \\
\hline military & 1 & 2 & friend & 8 & 16 & father & 1 & 2 & \\
\hline briefcase & 2 & 4 & player & 1 & 2 & active & 6 & 12 & \\
\hline desert & 1 & 2 & team member & 6 & 12 & researcher & 1 & 2 & \\
\hline toy & 1 & 2 & & & & sister & 1 & 2 & \\
\hline
\end{tabular}




\begin{tabular}{|c|c|c|c|c|c|c|c|c|c|}
\hline ВЕН. & $\mathbf{F}$ & $\mathbf{P}$ & COG. & $\mathbf{F}$ & $\mathbf{P}$ & SIT. & $\mathbf{F}$ & $\mathbf{P}$ & Total \\
\hline \multirow{4}{*}{ dictionary } & 1 & 2 & & & & plant & 3 & 6 & \\
\hline & & & & & & inventor & 2 & 4 & \\
\hline & & & & & & customer & 1 & 2 & \\
\hline & & & & & & thirsty & 3 & 6 & \\
\hline TOTAL & 8 & & & 22 & & & 20 & & 50 \\
\hline TOTAL & & 16 & & & 44 & & & 40 & \\
\hline
\end{tabular}

As it is presented in Table 3, and according to what we had up to now, it is not surprising to find out that male learners provided most metaphors in the cognitive andsituative category of learning $(\mathrm{p}=84 \%)$. Such metaphors reveal the learners wish to be an active $(\mathrm{p}=12 \%)$ person, a friend $(\mathrm{p}=16 \%)$, and a team member $(\mathrm{p}=12 \%)$ in class whose values are respected, his learning styles are magnified, and is encouraged to construct his knowledge individually, where the teacher as a FACILITATOR, a star, the sun, a consultant and a caterer tries to facilitate the learning, to show the right way when the learner has lost it and to provide all the needed things so that the learner himself construct the knowledge. So, there is no doubt that the learners can fulfill their potentials and develop their skills following the dynamics of cognitive and situative view of learning process (Pishghadam et al., 2011, p 98).

\subsection{Female Learners}

\subsubsection{Current Learners in Female Learners Point of View}

Based on Table 4, female learners hold the view that, although, some learners are following the situative domain of learning $(\mathrm{p}=22.39 \%)$ and as a flower $(\mathrm{p}=5.97 \%)$ and a passenger $(\mathrm{p}=5.97 \%)$ their needs are met carefully, most of them are categorized in behavioristic perspective $(\mathrm{p}=52.24 \%)$. Producing metaphors such as; sheep $(\mathrm{p}=$ $10.45 \%)$, statue $(\mathrm{p}=7.46 \%)$, vacuum cleaner $(\mathrm{p}=7.46 \%)$, female learners are going to show their distance with the teacher. They want to convey this fact that they are not involved in any decision in relation with their learning. Evidently, these learners believe that they are LEARNER AS RECIPIENT, and are not involved in classroom activities and/or making decisions for the changes in their learning process and certainly are not able to construct their knowledge of English in a friendly, cooperative connection with teacher and other learners (Pishghadam et al., 2011, p 102). Maybe looking at the given data from another point of view gives a better understanding of the situation;as you see, the results of this phase are similar to that of the male learners', where the other two categories of cognitive and situative, come under the dominance of behavioristic perspective. A brief look at the next table reveals that these learners do not like the current way of treatment to them anymore.

Table 4. The frequency and percentage of female learners' metaphors for learners in the current situation.

\begin{tabular}{|c|c|c|c|c|c|c|c|c|c|}
\hline BEH. & $\mathbf{F}$ & $\mathbf{P}$ & COG. & $\mathbf{F}$ & $\mathbf{P}$ & SIT. & $\mathbf{F}$ & $\mathbf{P}$ & total \\
\hline sheep & 7 & 10.45 & friend & 6 & 8.96 & patient & 2 & 2.99 & \\
\hline empty glass & 2 & 2.99 & good company & 4 & 5.97 & star & 1 & 1.49 & \\
\hline weak & 4 & 5.97 & sister & 1 & 1.49 & flower & 4 & 5.97 & \\
\hline statue & 5 & 7.46 & player & 1 & 1.49 & builder & 1 & 1.49 & \\
\hline exile & 1 & 1.49 & baby & 4 & 5.97 & passenger & 4 & 5.97 & \\
\hline eye & 3 & 4.48 & amateur swimmer & 1 & 1.49 & thirsty & 1 & 1.49 & \\
\hline mirror & 2 & 2.99 & & & & lawyer client & 1 & 1.49 & \\
\hline vacuum cleaner & 5 & 7.46 & & & & sun & 1 & 1.49 & \\
\hline sponge & 2 & 2.99 & & & & & & & \\
\hline desert & 4 & 5.97 & & & & & & & \\
\hline TOTAL & 35 & & & 17 & & & 15 & & 67 \\
\hline TOTAL & & 52.24 & & & 25.37 & & & 22.39 & \\
\hline
\end{tabular}

\subsubsection{Ideal Teachers in Female Learners Point of View}

Table 5. The frequency and percentage of female learners' metaphors for learners in the ideal situation.

\begin{tabular}{|c|c|c|c|c|c|c|c|c|c|}
\hline ВEH. & $\mathbf{F}$ & $\mathbf{P}$ & COG. & $\mathbf{F}$ & $\mathbf{P}$ & SIT. & $\mathbf{F}$ & $\mathbf{P}$ & total \\
\hline memory card & 1 & 1.52 & doctor assistant & 5 & 7.58 & builder & 3 & 4.55 & \\
\hline empty glass & 1 & 1.52 & good company & 2 & 3.03 & tourist & 4 & 6.06 & \\
\hline wall & 1 & 1.52 & friend & 9 & 13.64 & thirsty & 4 & 6.06 & \\
\hline copy machine & 1 & 1.52 & player & 4 & 6.06 & flower & 8 & 12.12 & \\
\hline eye & 4 & 6.06 & baby & 1 & 1.52 & inventor & 5 & 7.58 & \\
\hline mirror & 3 & 4.55 & sister & 1 & 1.52 & lawyer client & 2 & 3.03 & \\
\hline \multirow[t]{2}{*}{ sponge } & 3 & 4.55 & team member & 1 & 1.52 & patient & 1 & 1.52 & \\
\hline & & & & & & passenger & 1 & 1.52 & \\
\hline TOTAL & 14 & & & 23 & & & 29 & & 66 \\
\hline TOTAL & & 21.21 & & & 34.85 & & & 43.94 & \\
\hline
\end{tabular}


And finally, as Table 5 demonstrates in female learners' beliefs, a successful learner should be a friend $(\mathrm{p}=13.64 \%)$, a doctor assistant $(\mathrm{p}=7.58 \%)$ and a player $(\mathrm{p}=6.06 \%)$, where she acts based on cognitivist point of view and/or she should be an inventor $(\mathrm{p}=7.58 \%)$, a flower $(\mathrm{p}=12.12 \%)$, a tourist $(\mathrm{p}=6.06 \%)$, a thirsty $(\mathrm{p}=6.06 \%)$ person, all of which meet the principles of situative perspective $(\mathrm{p}=43.94 \%)$. And as (Pishghadam et al., 2011) put it: "...They seem to prefer a learning situation in which they can learn their best in special activities and contexts where they can construct the meaning socially and practice the use of language in true to life contexts" (p103). The related figure of this table (Figure 4.8) has more to talk about the metaphors in the categories outlined by Martinez et al. (2001); that is, female learners think they can learn better if they are provided with needed background activating related schemata, and just being guided during the exciting road of learning process. They want to be greatly involved in the process and play their turn.

\section{Discussion}

Analysis of the data showed that despite of the few number of the learners who act based on cognitive/constructivist $(\mathrm{p}=23.08)$ and situative or sociohistorical $(\mathrm{p}=22.22)$, like what Saban (2010) reports of the characteristics of such learners; "(1) The student is a growing being (e.g., apprentice and seed). (2) Learning is tied to the real life issues (e.g., chick, duckling, and newborn calf). (3) The teacher cares about the emotional well-being of each student in the classroom (e.g., fledgling, pet, seedling, son/daughter, and tortoise). (4) The most important job of the teacher is to support the growth of each student in the classroom (e.g., child, flower, kitten, and newborn baby)" (p 5), more than half of the participants produced metaphors about the current learners that are categorized in the behavioristic domain, where there is just a RECIPIENT who is treated as an empty glass, sponge, vacuum cleaner and memory card, which does not leave much space for theactivityof the leaner in the process of learning.This means, in Iran, still, most of the teachers work based on the principles of the behaviorists, consequently, these findings somehow reveal the maintenance of the behavioristic guidelines in language schools which are compatible with those of Pishghadam and Mirzaee (2008) and Pishghadam et al. (2011) who asserted that Iran's educational system is still under the influence of modernist, behaviorist and positivist views of learning.

On the other hand, the same participants by producing metaphors which expressed their preference for a greater involvement and a more intense interaction with the teacher and their peers, conveyed the fact that learning process is met in the situation within which these learners are aimed at strengthening their connection with the teacher, to get more involved in learning activities and construct their own meaning of English $(\mathrm{p}=38.79 \%)$. Their friend, colleague, child, player, baby and doctor assistant metaphors for the ideal learners conveying the conceptual metaphor of LEARNER AS DEVELOPING ORGANISM, reflects those learners' bold decision in promoting to a cognitive/constructivist class which reveals their understanding of their teachers' dysfunction in getting fruitful results from their present classes and the fact that they have faced a neglect of their needs.

In other words, today, what goes on in language classes in Iran mostly is a kind of memorizing, habit formation and conditioning activity which really is far apart from the real life goals of learning a language - communication.

For the second part of the first research question, the results demonstrate that, some of the learners $(p=42.24 \%)$ illustrated their opting for learning English in situative or socio-historical mode of learning. Producing metaphors like tourist, inventor, patient and builder for the ideal learners, confirm Stichert' (2005) study where she states: "Overall, results are showing that most of the participants agree with constructivist and social constructivist instructional orientations" (p 59).Based on Figure 4.12, they reinforce the theme of LEARNER AS INTERACTOR whose interaction in situated collaborative activities get him to enjoy much social support and stimulation for better learnin34g, draws more attention to learners' will to learn English in social processes and joint activities where knowledge is seen as situated, by-product of the activity, context and the culture in which it is developed and used (Pishghadam et al. 2011, p 101).

This finding is parallel with Sexton's (2004) claim where he reports: "Teachers who were judged to be good because they were seen as teachers who were "not teachers but people ... to be encouraged rather than a student". These teachers were seen as willing to go beyond the classroom boundaries and become involved in the students by actively encouraging, inspiring, and showing enthusiasm to and for their students. ( $\mathrm{p}$ 208)

In our second research question, our aim was to check the effect of gender on the learners' attitude toward language learning process. Though the numbers and values are not exactly the same (maybe if so we should be doubtful about the research and its results), the results of analyses and their comparison do not show a significant and meaningful difference between the ideas of male learners in comparison with those of the females'. To be more exact, while 58 percent of male learners think of their current learners as the followers of the behavioristic principles, 52.24 percent of female learners' metaphors categorized in the same perspective. Furthermore both genders have very close beliefs about the number of cognitivist $($ male $=20 \%$, female $=25.37 \%$ ) and situativist (male $=22 \%$, female $=22.39$ ) learners in current view. The comparison of the beliefs of these two groups about the ideal learner, also, shows the same result. That is, where only $16 \%$ of boys' ideal learners act based on behavioristic 
category, from the whole number of girls' ideal learners just $21.21 \%$ were in the behavioristic domain. And while male participants would prefer $44 \%$ cognitivist learners and $40 \%$ situativistlearners as their ideal learners (the total percent of these two categories is 84 ), $78.89 \%$ of female participants of this study believe that if their learners' approach to language learning is based on cognitivist $(\mathrm{p}=34.85 \%)$ and situativist $(\mathrm{p}=43.94 \%)$, they will certainly enjoy more of learning.

So for first null hypotheses (The gender has a significant effect on metaphors produced.), we have, now, a clear answer and that is; on the contrary to what Morady Moghadam \& Gholamzadeh (2011) found for culture which is gender based, the gender does not have a significant effect on metaphors produced about the learners in current and ideal situation. It is better to say, these metaphors are gender free. There, their results showed that the view of culture is to some extent gender based; in other words, males were more inclined toward negative aspects of culture but females were interested in positive features of culture (p 98).

\section{Conclusion}

The importance and great role of metaphors and their analysis on every part of our life including our education and language learning system is undeniable. According to Martinez, Sauleda and Huber (2001) by disclosing the metaphorical base of thinking about teaching and learning, researchers can assist learners to bridge the gap between their implicit and explicit knowledge. They suggest that "metaphors may function as stepping stones to a new vantage point from which a teacher can look at his or her own practice as an educator from a new perspective" (p. 974).The findings revealed a very painful fact which all our English classes in Iran suffer from. And that is nothing but the dominance of behaviorism and "positivists principles of reductionism" in our educational system. An approach about which Lyons (1981), more than thirty years ago, talks it in this way:Few linguists today would subscribe to the positivists principles of reductionism in the form in which Bloomfield and his fellow members of the Unity of Science movement did half-a-century ago(p 266). As the results show, high school students projected different expectations regarding the teachers. Disclosing and analyzing these metaphors can assist them gain insight into their real ideas about teaching and learning. First, since this study was conducted in a region with Turkish culture (Famenin city in Hamadan northeast), and the results of it are somehow close to that of Pishghadam et al. (2009) in Mashhad city with its different culture, one can easily conclude that metaphors about teaching learning are not culture dependent, rather, they are culture free.

Second, accordingly, the dominance of behaviorism is a matter that the learners of all parts of Iran suffer from. And all of them believe that the most appropriate way to end to this failure, is stepping toward cognitivism and situativism.
Third, another important finding of the study is maybe the inability of the learners of senior high school learners in producing their own metaphors. As it was mentioned before, prior to gathering the data, the researcher talked to all of the participants one by one and explained the whole process and suggested a table of metaphors developed by Pishghadam et al. (2011) as some examples to help them. But, interestingly, the results showed that all of the metaphors filled in the questionnaires by both male and female learners were based on the given table. That is, whether these leaners in this age or period have not improved enough to produce their own metaphors or the suggested metaphors were fully covering their purpose in spite of the many differences between these two regions (Mashhad and Famenin) first language, culture, and etc. These claims need to be investigated, of course.

Based on the results, the metaphors were categorized according to the three perspectives of behaviorist, cognitive and situative learning. The findings revealed a very painful fact which all our English classes in Iran suffer from. And that is nothing but the dominance of behaviorism and "positivists principles of reductionism" in our educational system. An approach about which Lyons (1981), more than thirty years ago, talks it in this way: "Few linguists today would subscribe to the positivists principles of reductionism in the form in which Bloomfield and his fellow members of the Unity of Science movement did half-a-century ago" (p 266).

As the results show, senior high school students projected different expectations regarding the teachers and students. Disclosing and analyzing these metaphors can assist them gain insight into their real ideas about teaching and learning.

$54.70 \%$ of the metaphors produced by senior high school students about students in the current situation suggested they perceive themselves as a follower of their teachers. The linguistic metaphors sheep, weak and eye emphasizing on the conceptual metaphor of LEARNER AS RECIPIENT, define a student as an inactive and passive person in classroom whose job is to receive whatever the teachers dictate. On the contrary, showing their will to reject "behaviorism" (This finding is in consistent with that of Stichert's (2005) where she reports: "The participants of the present study reject the behaviorist theory".) the majority of the metaphors produced about students in the ideal situation are in favor of the situative approach which is in consistent with the study done by Nikitina \& Furuoka, (2008; b). Apparently, students prefer to change their role as a passive recipient of knowledge and move toward an active partner in learning with their professors. They assume the metaphors doctor assistant, player and team member represent an ideal student who acquires knowledge as a by-product of doing a task. The conceptual metaphor of LEARNER AS INTERACTOR is behind these produced metaphors that suggest the role of students as doing situated tasks that can result in getting access to knowledge 
that can be used in real life situations. And as the results of Lin et al. (2012) study confirms:

The metaphor of a repairman or a doctor used by the participants views learners as individuals who possess deficiencies that must be fixed or treated by teachers. The goal of teaching focuses on a fixed outcome and accommodates the individual differences of learners. The teacher is like a mechanic who troubleshoots any brokendown car parts, or students. Students are in danger of falling to pieces, and the teacher must correct students' errors. This metaphor emphasizes that a teacher should remain current on innovative knowledge and use contemporary pedagogy to meet each individual's needs, just as a mechanic must always be aware of up-to-date motor technology(p 192).

Therefore, as the comparison between the ideal and current situations shows, both teachers and students suffer from the same problem which is the dominating belief that behaviorism is best suited for Iranian educational contexts, easing the process of learning and teaching because of keeping the power distance and also what our culture dictates. However, students prefer to learn based on the situative approach and be instructed by teachers who assert that the conventions of this approach can provide the best learning environment because it prepares them for actual use of their knowledge outside the classroom.

This study showed that the participants' beliefs were influenced not only by how they think about teaching but also by how they interpret the experience of language learning. The students' metaphors reflected individual values in language education, echoing the viewpoint of Connelly and Clandinin (1988) (as cited in Lin et al. 2012, $\mathrm{p}$ 195) that it "makes a great deal of difference to our practice...if we think of teaching as gardening, coaching, or cooking. It makes a difference if we think of children as clay to be moulded or as players on a team or as travellers on a journey" (p 71).

Identifying these underlying beliefs, students and teachers can reflect on their present styles of learning and teaching in order to find out the points that help or hinder their progress. The roles they consider for themselves and the underlying conceptions behind them can persist over time and change to erroneous beliefs that cannot be reformed, but metaphor analysis as a reflective tool assists both teachers and students to shed light on implicit ideas and assumptions, and challenge them in order to make a change in classroom practices. It can also heighten selfawareness which in time leads to making correct decisions for both students and teachers in selecting the right path for education. Another important point is that teachers and students can benefit from the findings of a metaphor analysis on their beliefs and try to alter the way they conduct the class and act according to the accepted guidelines of cognitive and situative perspectives. This study has the following implications: A) It is inevitable to develop a very huge movement within the whole system, from the beginning to end. That is from the curriculum to course books, to teacher training system, to approaches and etc. B) In other words, putting aside the guidelines of behaviorism, it is better to follow the principles of cognitivist/constructivist as for the first step toward improvement, what the learners of language institutes in Iran claim is going on in their EFL classes, and as Pishghadam and Mirzaee (2008) and Pishghadam et al. (2011) assert is the main reason for their successful experience in English learning. And then, as for the second step, move toward the principles of situativist perspective, whereas language learners of institutes see it as their ideal English class (Pishghadam et al. 2011) in order to experience a real life language. C) Based on what Farjami (2012) comments, with metaphors and mental images as guiding signposts for learners' thinking and conceptualization, the learning process can be understood as a process of metaphor or image change; in a pedagogy giving such a pivotal role to images, one important task of the teacher would certainly consist in facilitating the development of images that generate new learning or correct the existing learning. So a useful application of this study is for teachers to probe the foreign- language-related imagery of learners and then provide positive or negative feedback according to the results of their probes. I) by taking learners' metaphors into account and having image formation on the Instructional Agenda, Material Designers' Efforts Might Also Be Enhanced. They Can Design Language Awareness Lessons And Exercises Using A Host Of Images For Learners To Analyze And Connect The Features Of The Images To The Objectives Of The Lessons, For Example, Developing Skimming Skill. (Farjami2012, P 106) J) Parents And Professionals Should Take Their Turn And Try To Make Learning Joyful For The Learners. Jin Et Al. (2011) Puts It In This Way: Their Metaphors And Entailments Also Tell Us That Educational Professionals And Parents Need To Know How They Can Encourage These Learners By Giving Them Fun And Joy To Learn ( $\mathrm{P}$ 11).

This Research Like Any Other Studies Contained Some Limitations, Because As The Proponents Of Scientific Research Claim, Nothing Can Be Self-Evident Unless Verified By Observation Or Experimentation And Any Type Of Observation Or Experiment, May Face With Some Limitations And Problems. This Study Could Have Come To Somewhat More Different Results Than It Did, If It Were Not Confronted With The Following Limitations. First, This Study Was Conducted In Some High Schools In Famenin (A Small City In Hamadan Northwest-Iran) While More Research Can Take Place In All High Schools And Language Institutes In Famenin Or In Other Cities Of Iran To Have More Reliable Results. Second, Although All Of The Participants Had Been Qualified Through A Nationwide Exam At The End Of Their Grade Three, Language Level And Field Of Study Of The Participants Were Not Controlled. Third, This Study Was Conducted Among High School English Students; Junior High School/University Students Were Not Included. Fourth We 
Did Not Test The Performance Of The Participants In Producing Appropriate/Accurate Metaphors For Each Situation, Which Can Affect The Results. And Finally, Because Of The Abstract And Dynamic Nature Of Metaphor As Zhou \& Heineken (2009) Claim: The Meaning Of A Metaphor Is Not Necessarily Obvious And Constant And The Metaphor Comprehension Is Not A Static Process, But A Dynamic One. The Dynamics Of Metaphor Comprehension Can Be Demonstrated In The Following Two Aspects: 1) The Understanding Of A Metaphor May Vary From Person To Person, According To Their Relevant Pre-Existing Conceptual Knowledge; 2) Even The Same Person May Understand One Metaphor Differently In Different Contexts. In An Appropriate Context, Novel Metaphors Can Be Learned. The Dynamics Of Metaphor Comprehension Largely Results From The Complex Dynamic Systems Of Language, Thinking, Affect, Physicality And Culture, Of Which Metaphor Is A Part (P 38). The Researcher Categorized Some Of The Metaphors Based On What He Interpreted From The Produced Metaphor And/Or Its Entailments, Which May Affect The Results Somehow. Maybe It Is Better To Give A Complete List Of Previously Produced And Categorized Metaphors To The Learner To Choose From And Give Advices And Explanations Where Needed.

Certainly, As Farjami (2012) Notes, There Is A Lot Of Room For Further Research Beyond This Small Set Of Metaphors Elicited From A Limited Number Of Learners In Rather Similar Settings.(P 106) The Recommendations To The Researchers Who Would Like To Study A Similar Subject Are: 1) Clearly, Finding Out Teachers' Hidden Beliefs And Views And Trying To Get Into The Depth Of Their Belief System, Exploring The Parts Which Affect Teaching, Presenting The Hidden Ideas To The Teachers And Asking Teachers To Reflect On Them To Make Probable Changes Or Modifications Seem To Be An Inevitable Need In Iranian Contexts Of English Education. 2) Accordingly, Another Area Of Investigation Is The Beliefs About Other Factors, Such As The Schools And Classroom Environment. 3) May Be Another Area Of Research In Beliefs Which Is Noteworthy For English Education System In Iran Is The Learners And The Teachers Ideas About The Current And Ideal Course Books. 4) As Stichert (2005) Puts It: "The Variation Of The Perceptions Should Be Monitored Across Years As A Long Term Study". So, We Suggest A Longitudinal Study To Have More And Clearer Information. 5) Effects Of Different Variables, Like Past Experiences Or The Private Institutes' Experience, On Perception Of Learners About The Whole Process Can Be Analyzed.

\section{Appendixes}

\section{Appendix A}

Your name: .........

Your age:
What is your idea of a language learner?

Try to complete the following sentence in as many ways to reflect your ideas of a language learner. Include any explanations, and/or entailments, if needed.

$>$ A language learner is like...

$\bullet$

What is your idea of an ideal language learner?

Try to complete the following sentence in as many ways to reflect your ideas of an ideal language learner. Include any explanations, and/or entailments, if needed.

$>$ An ideal language learner should be like...

\section{Appendix B}

Table 1. A part of categorized Metaphors about learners (developed by Pishghadam et al. 2011)

\begin{tabular}{|c|c|c|}
\hline behaviorist & cognitive/constructive & $\begin{array}{l}\text { situative/socio- } \\
\text { historic }\end{array}$ \\
\hline $\begin{array}{l}\text { Sheep (with no will } \\
\text { on his side you } \\
\text { follows his teacher) }\end{array}$ & $\begin{array}{l}\text { child(learns better when his } \\
\text { parent help him) }\end{array}$ & $\begin{array}{l}\text { flower(when } \\
\text { learning situation is } \\
\text { demanding, teacher } \\
\text { and others will enjoy } \\
\text { having him in class) }\end{array}$ \\
\hline $\begin{array}{l}\text { goat(just follows his } \\
\text { teacher) }\end{array}$ & $\begin{array}{l}\text { friend(with having a } \\
\text { friendly relationship with } \\
\text { teacher learns best) }\end{array}$ & $\begin{array}{l}\text { plant(needs care and } \\
\text { attention while is } \\
\text { growing) }\end{array}$ \\
\hline $\begin{array}{l}\text { exile(after making a } \\
\text { mistake in class the } \\
\text { teacher looks at him } \\
\text { as guilty not } \\
\text { allowing to more } \\
\text { participation) }\end{array}$ & $\begin{array}{l}\text { good company(everybody } \\
\text { trusts him in class, you can } \\
\text { learn better being with } \\
\text { him) }\end{array}$ & $\begin{array}{l}\text { thirsty(teacher can } \\
\text { provide him with } \\
\text { suitable learning } \\
\text { material when he } \\
\text { needs) }\end{array}$ \\
\hline $\begin{array}{l}\text { empty glass(teacher } \\
\text { can fill him with } \\
\text { whatever anytime he } \\
\text { wants) }\end{array}$ & $\begin{array}{l}\text { player(can play with } \\
\text { teacher and others to learn } \\
\text { better) }\end{array}$ & $\begin{array}{l}\text { tourist(learns things } \\
\text { as if is travelling to } \\
\text { new places) }\end{array}$ \\
\hline $\begin{array}{l}\text { stone(no movement, } \\
\text { no creativity, no } \\
\text { will) }\end{array}$ & $\begin{array}{l}\text { sister(is reliable and kind to } \\
\text { other students and teacher) }\end{array}$ & $\begin{array}{l}\text { inventor(with } \\
\text { teacher help, can } \\
\text { find out novel } \\
\text { learning styles in } \\
\text { novel situations) }\end{array}$ \\
\hline $\begin{array}{l}\text { statue(motionless, } \\
\text { being passive in } \\
\text { class) }\end{array}$ & $\begin{array}{l}\text { spouse(can support other } \\
\text { students and teacher) }\end{array}$ & $\begin{array}{l}\text { lawyer } \\
\text { client(consults to } \\
\text { solve his problem) }\end{array}$ \\
\hline $\begin{array}{l}\text { recorder(just records } \\
\text { what he hears) }\end{array}$ & $\begin{array}{l}\text { team member(can play } \\
\text { with teacher and others in a } \\
\text { team to win learning) }\end{array}$ & $\begin{array}{l}\text { builder(teacher helps } \\
\text { and supervise him to } \\
\text { make whatever he } \\
\text { wants) }\end{array}$ \\
\hline $\begin{array}{l}\text { sponge(absorbs the } \\
\text { knowledge as it is } \\
\text { with no activity) }\end{array}$ & $\begin{array}{l}\text { baby(needs care and } \\
\text { attention from teacher to } \\
\text { learn better) }\end{array}$ & $\begin{array}{l}\text { car } \\
\text { passenger(teacher } \\
\text { carries him in his car } \\
\text { to learning } \\
\text { destination) }\end{array}$ \\
\hline $\begin{array}{l}\text { recipient (just } \\
\text { receives what is said } \\
\text { in class, no activity) }\end{array}$ & $\begin{array}{l}\text { amateur swimmer(teacher } \\
\text { provides suitable water for } \\
\text { him to swim and learn) }\end{array}$ & $\begin{array}{l}\text { TV-show } \\
\text { contestant(in a } \\
\text { special situation acts } \\
\text { with teacher help to } \\
\text { win) }\end{array}$ \\
\hline $\begin{array}{l}\mathrm{CD} \text { (is recorded by } \\
\text { whatever teacher } \\
\text { pleases) }\end{array}$ & $\begin{array}{l}\text { doctor assistant(will help } \\
\text { and learn from teacher } \\
\text { while they do something }\end{array}$ & $\begin{array}{l}\text { patient(when fails in } \\
\text { learning, gets better } \\
\text { by teacher's help) }\end{array}$ \\
\hline
\end{tabular}




\begin{tabular}{|c|c|c|}
\hline behaviorist & cognitive/constructive & $\begin{array}{l}\text { situative/socio- } \\
\text { historic }\end{array}$ \\
\hline $\begin{array}{l}\text { computer(teacher } \\
\text { fills him with any } \\
\text { kind of data and } \\
\text { program he favours) } \\
\text { vacuum cleaner(pre- } \\
\text { programmed to take } \\
\text { in the information in } \\
\text { class, no learning } \\
\text { activity) } \\
\text { mirror(he must only } \\
\text { reflect the teacher, } \\
\text { no creativity on his } \\
\text { side) } \\
\text { desert(is looked at } \\
\text { as empty of } \\
\text { knowledge, } \\
\text { motivation and will } \\
\text { to go on) } \\
\text { Doll(it can be } \\
\text { played with) } \\
\text { eye(just observes } \\
\text { what is going on, no } \\
\text { activity) } \\
\text { toy(it can be played } \\
\text { with) } \\
\text { piano(teacher can } \\
\text { play any melody he } \\
\text { wants out of it) } \\
\text { copy machine(just } \\
\text { copies the } \\
\text { information he } \\
\text { receives) } \\
\text { memory card(is } \\
\text { filled with data, no } \\
\text { activity) } \\
\text { suitcase(teacher can } \\
\text { pack it with } \\
\text { anything he prefers, } \\
\text { he just carries them) }\end{array}$ & together) & $\begin{array}{l}\text { customer(like a } \\
\text { customer chooses } \\
\text { what and how to buy } \\
\text { his needs) }\end{array}$ \\
\hline
\end{tabular}

\section{References}

[1] Botha, E. (2009). Why metaphor matters in education. South African Journal of Education [2009] Vol.29, $431-444$

[2] Ding, E. \& Kong, H. (2009).Metaphor and Culture. Asian Social Science, [2009], Vol. 5, No. 1.

[3] Ellis, R. (2008). Learner beliefs and language learning. The Asian EFL Journal Quarterly, Vol. 10 (4), 7-25

[4] Farjami H. (2012). EFL learners' metaphors and images about foreign language learning. Studies in Second Language Learning and Teaching. Department of English Studies, Faculty of Pedagogy and Fine Arts, Adam Mickiewicz University, Kalisz. SSLLT 2 (1) [2012]. 93-109. http://www.ssllt.amu.edu.pl

[5] Glogowski K. (2012). Teaching Metaphors. [2012]. http://getideas.org/getinsight/teaching- metaphors/

[6] Gunbayi, I. (2011). Principals' Perceptions on School
Management: A Case Study with Metaphorical Analysis. International Online Journal of Educational Sciences, [2011], 3(2), 541-561.

[7] Jin, L., Smith, K., Yahya, A., Chan, A., Choong, M., Lee, A., $\mathrm{Ng}$, V., Poh-Wong, P. \& Young, D. (2011).Perceptions and Strategies of Learning in English by Singapore Primary School Children with Dyslexia - a metaphor analysis.ELT Research Papers11-03.Montfort University and the Dyslexia Association of Singapore.

[8] Lakoff, G. \& Johnson, M. (1980).Metaphors we live by. Chicago: University of Chicago Press.

[9] Larsen-Freeman D. (1986).Techniques and Principles in Language Teaching. Oxford: Oxford University Press.

[10] Lin, W., Shein, P. \&Yang, S. (2012). Exploring personal EFL teaching metaphors in pre-service teacher education. English Teaching Practice and Critique, Volume 11, [2012], Number 1, pp. 183-19 http://education.waikato.ac.nz/research/files/etpc/files/2012 v11n1dial3.pdf

[11] Lyons J. (1981).Language and linguistics, Cambridge: Cambridge University Press.

[12] Martinez, M.A., Sauleda, N., \& Huber, G.L. (2001). Metaphors as blueprints of thinking about teaching and learning. Journal of Teaching and Teacher Education, 17, 965-977

[13] Morady Moghaddam, M. \& Gholamzadeh, M. (2011).Delving into EFL Learners' Cultural Conceptions through Metaphor Analysis. Cross-cultural Communication, [2011],7 (4), 91-100.

[14] Nikitina, L., \& Furuoka, F. (2008). "A Language Teacher is Like...": Examining Malaysian students' perception of language teachers through metaphor analysis. Electronic Journal of Foreign Language Teaching, 5 (2), 192-205

[15] Pishghadam, R. (2008). The content analysis of the books for English language learning in Iran's formal and informal contexts of language education in light of MI, EI and mediation theory. (Paper presented in the first conference on formal education. Iran, Ferdowsi University.)

[16] Pishghadam, R., \& Mirzaee, A. (2008).English language teaching in postmodern era.TELL, 2,89-109.

[17] Pishghadam, R., Askarzadeh Torghabe, R., \&Navari, S. (2009). Metaphor analysis of teachers' beliefs and conceptions of language teaching and learning in Iranian high schools and language institutes: A qualitative study. Iranian EFL Journal, 4, 6-40

[18] Pishghadam, R., Navari, S. (2010). Examining Iranian language learners' perceptions of language education in formal and informal contexts: A quantitative study. MJAL, 2 (1), 171-185

[19] Pishghadam, R., Hosseini Fatemi, A., Askarzadeh Torghabe, R., \&Navari, S. (2011). Qualitative Metaphor Analysis and Language Learning Opportunities. IJAL, Vol. 14, No. 1, [2011], pp 81-115.

[20] Pishghadam, R., Pourali, S.(2011). Iranian PhD Students' Beliefs about Language Learning and Teaching: A Qualitative Study. World Journal of Education Vol . 1, No. 1; [2011], pp 63-71. www.sciedu.ca/wje 
[21] Pishghadam, R., Pourali, S.(2011). Metaphorical Analysis of Iranian MA University Students' Beliefs: A Qualitative Study. Higher Education Studies Vol. 1, No. 1; [2011], pp 27-37. www.sciedu.ca/wje

[22] Rahmani Samani, E. \& Hashemian, M. (2012).The Effect of Conceptual Metaphors on Learning Idioms by L2 Learners. International Journal of English Linguistics Vol. 2, [2012] No. 1; 249-256. www.ccsenet.org/ijel

[23] Sexton.S. (2004).Prior Teacher Experiences Informing How Post-Graduate Teacher Candidates See Teaching and Themselves in the Role as the Teacher. International Education Journal Vol 5, No 2, 2004 http://iej.cjb.net

[24] Skaftun, A. (2011). Minding Metaphors: Rethinking the Ecology of Written Language. L1-Educational Studies in Language and Literature, 11, 39-50.

[25] Stichert, G. E. (2005). Preservice Science Teachers
Perception of Profession with Metaphorical Images and Reasons of Choosing Teaching as a Profession. A Thesis Submitted to The Graduate School of Natural and Applied Sciences of middle east Technical University of Ankara, Turkey [ 2005].

[26] Yillmaz, R. (2010). Understanding learners' beliefs of language learning, learners, and teachers through their personal metaphors. An Action Research Project for GEDIZ UNIVERSITY.

[27] Zhang, F., Hu, J. (2009).A Study of Metaphor and its Application in Language learning and Teaching. International L Education Studies Vol. 2, No. 2 [2009], 7781.

[28] Zhou, D. \& Heineken, E. (2009). The use of metaphors in academic communication: traps or treasures. Ibérica 18 [2009], 23-49. 